\title{
Physiological Studies on Cancer irroratus Larvae. II. Effects of Temperature and Salinity on Physiological Performance*
}

\author{
D. Michael Johns
}

United States Environmental Protection Agency, Environmental Research Laboratory, South Ferry Road, Narragansett, Rhode Island 02882, USA

and

Belle W. Baruch Institute for Marine Biology and Coastal Research, University of South Carolina, Columbia, South Carolina 29208, USA

\begin{abstract}
Larvae of the rock crab Cancer irroratus were cultured under specific environmental regimes to examine the influence of temperature and salinity on respiration and excretion rates during development. In addition, the type of biochemical substrate used for energy production was determined. The allometric relationship between oxygen consumption and body weight $\left(\mathrm{VO}_{2}\right)$ was found to be affected by temperature but not by salinity. Larvae cultured at $10^{\circ} \mathrm{C}$ exhibited a significantly $(\mathrm{P} \leq$ $0.05)$ higher regression coefficient (1.35) than did larvae maintained at either $15^{\circ}(0.80)$ or $24^{\circ} \mathrm{C}(0.87)$. In contrast, the relationship of ammonia excretion rate $\left(\dot{V}_{\mathrm{NH}-\mathrm{N}}\right)$ to body weight were not affected by temperature but were affected by salinity. Larvae cultured in $15^{\circ} \mathrm{C}$ at $25 \%$ S released significantly greater amounts of ammonia than did larvae of similar size at either $30 \%$ or $35 \%$ S. The atomic ratio of oxygen consumed to nitrogen excreted, the $O: N$ ratio, fluctuated during development for larvae maintained in all environmental regimes tested. For larvae cultured at $10 \% / 30 \% \mathrm{~S}$, the O:N ratio was low indicating that protein was the primary substrate used as an energy source. At the other conditions tested, the $\mathrm{O}: \mathrm{N}$ ratio generally remained high indicating a combined use of protein, lipids and carbohydrates as energy sources. These data suggest that the successful development and recruitment of rock crab larvae is influenced by environmental conditions within their tolerance limits where physiological performance is impaired to such an extent that they are less fit to effectively compete within the zooplankton community.
\end{abstract}

\section{INTRODUCTION}

Laboratory studies have furthered our understanding of the effects of environmental conditions on the development of brachyuran larvae. Tolerance to temperature and salinity levels have been established for many species (Costlow and Bookhout, 1962; Costlow et al., 1966; see Marine Ecology': Kinne, 1970, 1971, 1977 for reviews). Within the zone of tolerance, environmental conditions have been shown to affect development rate, intermolt duration and growth (Costlow and Bookhout, 1971; Christiansen and Costlow, 1975; Johns, 1981).

\footnotetext{
- Contribution No. 201 from EPA Environmental Research, Laboratory, Narragansett, Rhode Island and Contribution No. 417 from the Belle W. Baruch Institute for Marine Biology and Coastal Research
}

In addition, studies have assessed the impact of environmental variation on the function of physiological and biochemical systems in crab larvae. Some work has been reported for respiratory rates and metabolictemperature responses of several species under contrasting conditions (Vernberg and Costlow, 1966; Belman and Childress, 1973; Sastry and McCarthy, 1973; Schatzlein and Costlow, 1978; Sastry, 1979), as have works detailing the osmoregulatory ability of developing larvae (Kalber and Costlow, 1966; Kalber and Costlow, 1968; Foskett, 1977). Biochemical changes brought about by differing environmental conditions have also been considered (Frank et al., 1975; Sulkin et al., 1975; Tucker, 1977; Morgan et al., 1978; Sastry and Ellington, 1978).

Although the above studies give an appreciation for the range of responses of individual physiological and biochemical systems to environmental variations, no 
single study has considered the integration of these systems into a whole organism response. Such a holistic approach is needed to adequately interpret the effects of the environment on larval development since organisms seldom respond to environmental change through adjustments in an individual physiological or biochemical rate but rather respond as an integrated whole.

A series of experiments were designed to study the effects of specific environmental regimes on larval development of the rock crab Cancer irroratus. The effects of temperature and salinity on survival, development rate, intermolt duration and larval size were determined (Johns, 1981). Further, an investigation was made of the energy balance of the larvae at various environmental conditions to determine how temperature and salinity affect energy flow (Johns, 1980). The present paper examines the influence of temperature and salinity on the physiological response of rock crab larvae and the degree to which respiration and excretion rates are integrated during development. In addition, the type of biochemical substrate used for energy production was determined.

\section{MATERIALS AND METHODS}

Gravid Cancer irroratus were collected by otter trawl from the West Passage of Narragansett Bay, Rhode Island, from December to May of 1977 through 1979. Methods for laboratory maintenance of the gravid adults, procurement of newly-hatched zoeae and the mass culture techniques used in this study are presented in detail elsewhere (Johns, 1981).

Respiration rates, excretion rates and the calculation of an $\mathrm{O}: \mathrm{N}$ ratio were made for larvae cultured in the following temperature-salinity conditions: $10^{\circ} \mathrm{C} / 30 \%$ S, $15{ }^{\circ} \mathrm{C} / 25 \%$ S, $15{ }^{\circ} \mathrm{C} / 30 \%$ S, $15^{\circ} \mathrm{C} / 35 \%$ S, $24{ }^{\circ} \mathrm{C} /$ $30 \%$ S. Respiration rates and excretion rates were determined for all 5 zoeal stages. These determinations were made between 24 and 36 h after hatching (for Stage I zoeae). For all other stages, the larvae used in the experiments were between 24 and $36 \mathrm{~h}$ following the molt from the previous larval stages. Mean molting times for each larval stage were taken from a concurrent study (Johns, 1981). All larvae were fed daily with newly-hatched Brazilian-strain Artemia (Johns et al., 1980).

Routine oxygen consumption rates were determined with all glass micro-respirometers (Grunbaum et al., 1955) having a $0.3 \mathrm{~mm}$ capillary bore. The number of zoeae used in each determination varied with larval size and ranged from 6 larvae for Stage I zoea to l larva for Stage $V$ zoea. The respirometers were allowed to equilibriate for at least $30 \mathrm{~min}$ prior to the initial readings; readings were taken every 15 min for $3 \mathrm{~h}$. To avoid interference from possible circadian patterns of respiration, all determinations were made between 1200 and $1800 \mathrm{~h}$. Following the respiration run, the crab larvae were rinsed in $0.9 \%$ ammonium formate (W: V), dried in a $60^{\circ} \mathrm{C}$ oven for $24 \mathrm{~h}$ and weighed on a Perkin-Elmer Autobalance ${ }^{*}$ to the nearest $1.0 \mu \mathrm{g}$.

Excretion rates were determined for groups of larvae that were placed in $10 \mathrm{ml}$ of $0.45 \mu \mathrm{m}$ filtered seawater for up to $5 \mathrm{~h}$. As in the respiratory rate determinations, the number of zoeae used for each determination depended on larval size. For zoeal Stages I and II, 10 larvae were used, with 8 larvae being utilized for Stage III and 5 larvae for both Stages IV and V. Ammonia concentrations were determined after Solorzano (1969). In addition, atomic $\mathrm{O}: \mathrm{N}$ ratios were calculated for each larval stage to determine types of biochemical substrate used for energy production (Corner and Cowey, 1968).

The allometric relationship of both respiratory rate and excretory rate to body size was fitted to the following equation:

$$
M=a W^{0}
$$

where $M=$ oxygen consumption rate or ammonia excretion rate; $W=$ weight; $a$ and $b=$ constants. Using log-transformed data, the above mathematical relationship was fitted to a linear model using least square linear regression analysis. Subsequent statistical tests (analysis of covariance) could then be used to determine the effects of rearing conditions on these size-dependent relationships (Snedecor and Cochran, 1967)

The influence of larval development on weightspecific respiration rates was determined using oneway analysis of variance. If significant differences (at $\mathrm{P}$ $=0.05$ ) were found among the treatments at each zoeal stage, a Duncan's Multiple Range test was used to determine where the differences occurred (Snedecor and Cochran, 1967).

\section{RESULTS}

The relationship between oxygen consumption $\left(\mathrm{V}_{0_{2}}\right)$ and body size for Cancer irroratus larvae maintained at various temperatures in $30 \% \mathrm{~S}$ was linear (Fig. 1). At all temperatures tested, $\vec{V}_{\mathrm{O}_{2}}$ increased with increasing body weight. The regression coefficient $(b, a$ measure of the proportionality of respiratory rate to body weight), for larvae cultured at $15^{\circ} \mathrm{C}(b=0.80)$ and $24^{\circ} \mathrm{C}(b=0.87)$, was not significantly different from

\footnotetext{
- Mention of trade names does not imply endorsement by the United States Environmental Protection Agency
} 


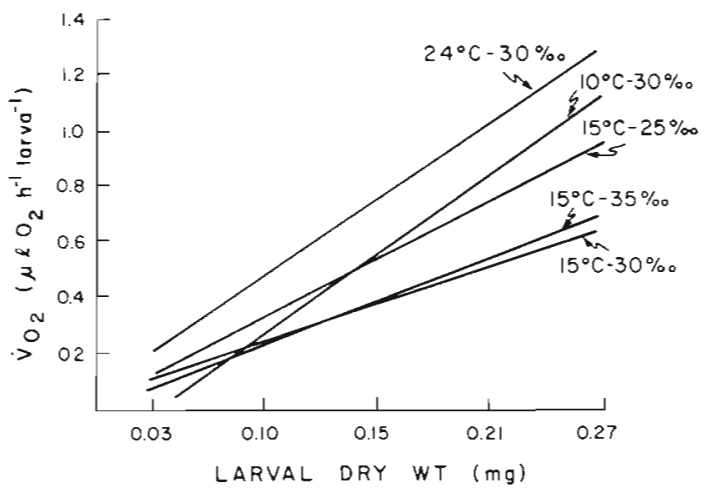

Fig. 1 Cancer irroratus. Respiration rates $\left(\dot{V}_{0_{2}}\right)$ of larvae cultured in various combinations of temperature and salinity Plotted lines represent $\log$ transformed data fitted to the linear regression model: $\log \dot{V}_{0_{2}}=\log a+b \log$ dry wt. Use Table 1 for numerical parameters and correlation coefficients of these lines

Table 1. Cancer irroratus. Parameters of fitted regression lines, and their correlation expressing the allometric relationship of $\dot{V}_{0}$ and body weight for zoeal stages cultured at various conditions of temperature and salinity. (n): number of respiration rate determinations; $b$ : regression coefficient for the fitted regression line; $r$ : correlation coefficient

\begin{tabular}{|c|c|c|c|c|}
\hline $\begin{array}{c}\text { Culture } \\
\text { Condition } \\
\left({ }^{\circ} \mathrm{C}\right)- \\
(\% \mathrm{~S})\end{array}$ & (n) & $b$ & $r$ & Regression line \\
\hline $10-30$ & 30 & 1.35 & .91 & $\log \dot{V}_{v_{2}}=0.62+1.35 \log$ dry wt. \\
\hline $15-25$ & 30 & 0.97 & .90 & $\log \mathrm{V}_{0 .}=0.56+0.97 \log$ dry wt. \\
\hline $15-30$ & 90 & 0.80 & 78 & $\log \mathrm{V}_{\mathrm{u}_{z}}=0.35+0.80 \log \mathrm{d} r \mathrm{y} w \mathrm{t}$ \\
\hline $15-35$ & 30 & 0.93 & .95 & $\log \dot{V}_{0_{2}}=0.40+0.93 \log$ dry wt. \\
\hline $24-30$ & 30 & 0.87 & .90 & $\log V_{Q_{z}}=0.69+0.87 \log$ dry wt. \\
\hline
\end{tabular}

each other; however, both of these values were significantly lower than the regression coefficient for larvae reared at $10^{\circ} \mathrm{C}(b=1.35$; Table 1$)$.

Salinity did not appear to influence the $\dot{V}_{0_{2}}$ to body size relationship (Fig. 1). Regression lines for larvae cultured in 3 salinities $\left(25,30\right.$, and $35 \%$ S) at $15^{\circ} \mathrm{C}$

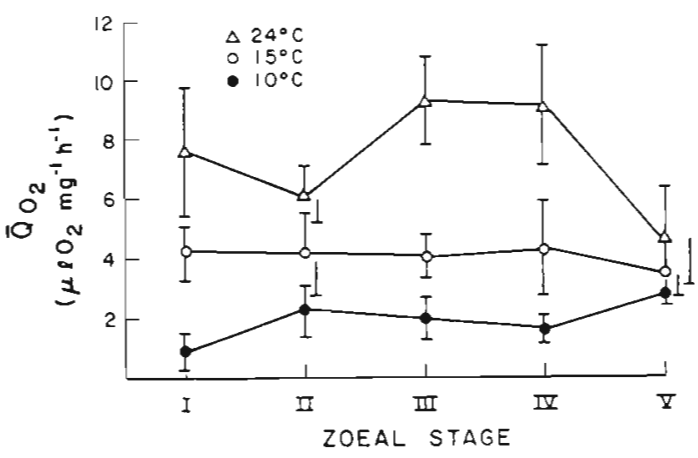

Fig. 2. Cancer irroratus. Weight-specific respiration rates (mean \pm 1 std. deviation) for larvae cultured at various temperatures in $30 \% \mathrm{~S}$
Table 2. Cancer irroratus. Analysis of variance of interstage weight-specific respiration rates for zoeal stages cultured at various conditions of temperature and salinity

\begin{tabular}{|c|c|c|c|c|}
\hline $\begin{array}{c}\text { Culture } \\
\text { condition } \\
\left({ }^{\circ} \mathrm{C}\right)-(\% \mathrm{~S})\end{array}$ & S.S. & d.f. & M.S. & F-Ratio \\
\hline \multicolumn{5}{|l|}{$10-30$} \\
\hline Treatment & 10.97 & 4 & 2.74 & - \\
\hline Error & 7.64 & 19 & 0.40 & - \\
\hline Total & 18.61 & 23 & - & $6.82^{\circ}$ \\
\hline \multicolumn{5}{|l|}{$15-35$} \\
\hline Treatment & 7.01 & 4 & 1.75 & - \\
\hline Error & 68.23 & 55 & 1.24 & - \\
\hline Mean & 75.24 & 59 & - & 1.41 \\
\hline \multicolumn{5}{|l|}{$15-30$} \\
\hline Treatment & 5.11 & 4 & 1.28 & - \\
\hline Error & 95.66 & 68 & 1.41 & - \\
\hline Total & 100.68 & 72 & - & 0.91 \\
\hline \multicolumn{5}{|l|}{$15-35$} \\
\hline Treatment & 8.33 & 4 & 2.08 & - \\
\hline Error & 38.86 & 22 & 1.68 & - \\
\hline Total & 45.19 & 26 & - & 1.24 \\
\hline \multicolumn{5}{|l|}{$24-30$} \\
\hline Treatment & 81.38 & 4 & 20.35 & - \\
\hline Error & 85.66 & 21 & 4.08 & - \\
\hline Total & 167.04 & 25 & - & $4.99^{\circ}$ \\
\hline
\end{tabular}

were not significantly different $(F=1.58$, d. f. 2,34$)$ according to an analysis of equality of the three regression lines. Although regression coeffients for these lines ranges from 0.80 to 0.97 , the variaton in $\dot{V}_{0_{2}}$ at each salinity did not allow for statistical differentiation $(\mathrm{P}=0.05)$ of the data (Table 1$)$

Interstage weight-specific respiration rates $\left(\bar{Q}_{0_{2}}\right)$ for larvae cultured in $30 \% \mathrm{~S}$, but at different temperatures, varied to some degree (Fig. 2). At $15^{\circ} \mathrm{C}, \overline{\mathrm{Q}}_{\mathrm{O}_{2}}$ rates were similar in all 5 zoeal stages. At the other 2 temperatures tested, however some differences in weight-specific respiration were found (Table 2). Despite the stage-to-stage differences seen in larvae cultured at $10^{\circ}$ and $24^{\circ} \mathrm{C}$, the basic pattern of con-

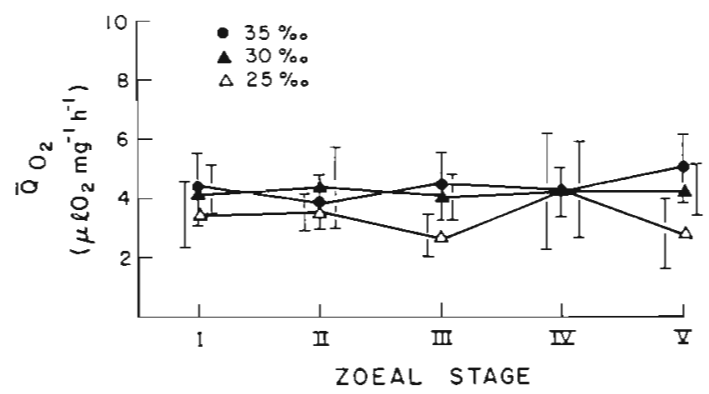

Fig. 3. Cancer irroratus. Weight-specific respiration rates (mean \pm 1 std. deviation) for larvae cultured in various salinities at $15^{\circ} \mathrm{C}$ 
stancy in $\bar{Q}_{0,}$ during zoeal development exhibited by larvae maintained at $15^{\circ} \mathrm{C}$ is still apparent.

Salinity had very little effect on weight-specific respiration rates for larvae maintained at $15^{\circ} \mathrm{C}$ (Fig. 3). No significant differences were found in $\overline{\mathrm{Q}}_{\mathrm{O}_{2}}$ between any of the zoeal stages of rock crab larvae cultured in 25,30 , and $35 \%$ S (Table 2).

The allometric relationship of excretion rate $\left(\mathrm{V}_{\mathrm{NH}_{4}-\mathrm{N}}\right)$ to body weight for larvae maintained under various temperature-salinity conditions is presented in Fig. 4.

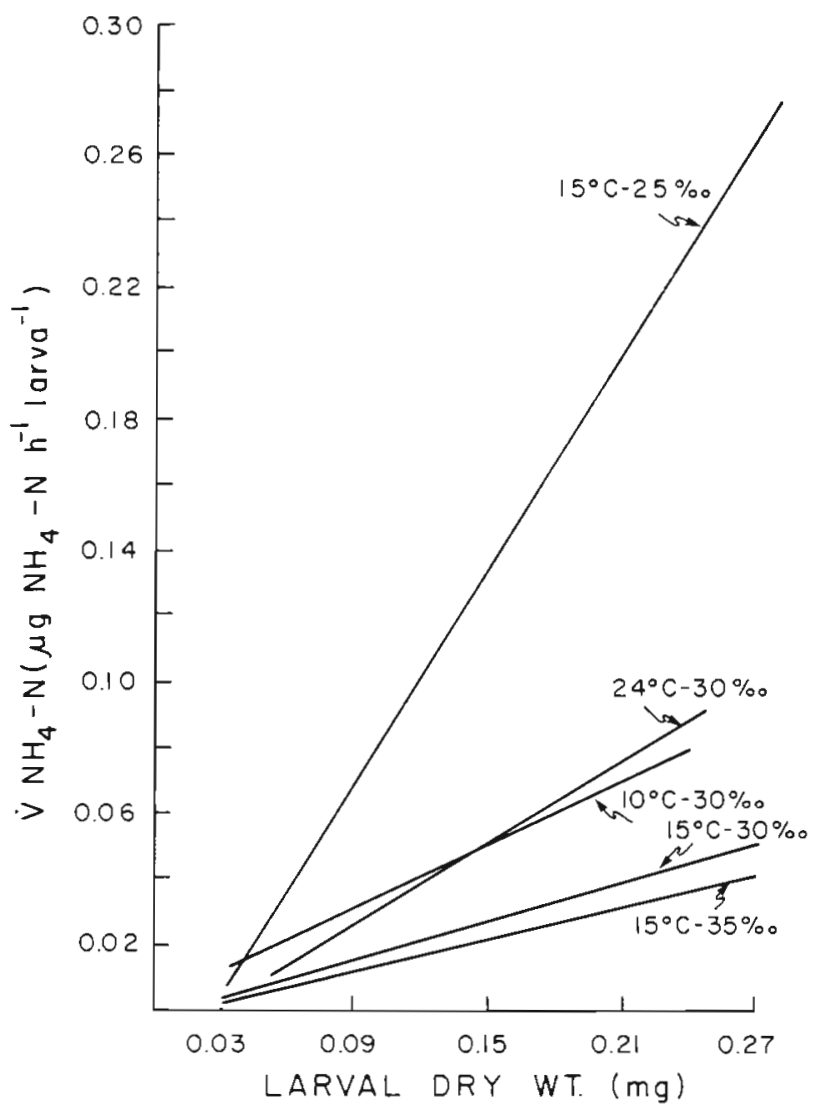

Fig. 4. Cancer irroratus. Excretion rates $\left(\dot{\mathrm{V}}_{\mathrm{NH}_{4}-\mathrm{N}}\right)$ of larvae cultured at various combinations of temperature and salinity. Plotted lines represent log transformed data fitted to the linear regression model: $\log \mathrm{V}_{\mathrm{NH}_{4}-\mathrm{N}}=\log \mathrm{a}+\mathrm{b} \log$ dry wt.; use Table 3 for numerical parameters and correlation coefficients of these lines

In all cases, the regression coefficient, $b$, for the fitted regression lines was greater than 1.00 (Table 3). Temperature appears to have a constant effect on this allometric relationship since the regression coefficients for larvae culture at $10^{\circ}, 15^{\circ}$ and $24^{\circ} \mathrm{C}$ were not significantly different from each other. The intercept of the 3 regression lines were different, however, indicating that larvae cultured at $10^{\circ}$ and $24^{\circ} \mathrm{C}$ liberate significantly lower amounts of ammonia than larvae of a similar size maintained at $15^{\circ} \mathrm{C}$.
Table 3. Cancer irroratus. Parameters of fitted regression lines, and their correlation coefficients expressing the allometric relationship of $\mathrm{V}_{\mathrm{NH}_{4}-\mathrm{N}}$ and body weight for zoeal stages cultured at various conditions of temperature and salinity. (n): number of excretion rate determinations; $b$ : regressions coefficient for the fitted regression line; $r$ : correlation coefficient

\begin{tabular}{|c|c|c|c|c|}
\hline $\begin{array}{c}\text { Culture } \\
\text { condi- } \\
\text { tion } \\
\left({ }^{\circ} \mathrm{C}\right)- \\
(\% \mathrm{~S})\end{array}$ & (n) & $b$ & $r$ & Regression line \\
\hline $10-30$ & 23 & 1.15 & .94 & $\log \mathrm{V}_{\mathrm{NH}_{4} \mathrm{~N}}=-0.34+1.15 \log$ dry wt. \\
\hline $15-25$ & 24 & 1.54 & .91 & $\log V_{\mathrm{NH}_{4}-\mathrm{N}}=+0.21+1.54 \log$ dry $w \mathrm{t}$. \\
\hline $15-30$ & 35 & 1.12 & .91 & $\log \mathrm{V}_{\mathrm{NH}_{4}-\mathrm{N}}=-0.59+1.12 \log \mathrm{dry} w t$ \\
\hline $15-35$ & 22 & 1.15 & .94 & $\log V_{\mathrm{NH}_{4}-\mathrm{N}}=-0.65+1.15 \log$ dry wt. \\
\hline $24-30$ & 27 & 1.25 & .84 & $\log \dot{V}_{\mathrm{NH}_{4}-\mathrm{N}}=-0.24+1.25 \log$ dry wt. \\
\hline
\end{tabular}

Salinity affected the amount of ammonia liberated by the rock crab larvae with $\dot{\mathrm{NH}}_{\mathrm{H}_{4} \mathrm{~N}}$ increasing as size increased and salinity decreasted (Table 3). Larvae cultured at $25 \% \mathrm{~S}(b=1.54)$ released significantly $(P \leq 0.05)$ greater amounts of ammonia than did larvae of a similar size at either $30 \% \mathrm{~S}(b=1.12)$ or $35 \% \mathrm{~S}(b$ $=1.15$ ).

The atomic ratio of oxygen consumed to nitrogen excreted, the $\mathrm{O}: \mathrm{N}$ ratio, fluctuated during larval development for larvae reared in all conditions tested

Table 4. Cancer irroratus. Calculated $O: N$ ratios for zoeal stages cultured at various conditions of temperature and salinity

\begin{tabular}{|crrrrr|}
\hline & \multicolumn{5}{c|}{ Culture condition $\left({ }^{\circ} \mathrm{C}\right)-(\% \mathrm{~S})$} \\
Zoeal stage & $10-30$ & $15-25$ & $15-30$ & $15-35$ & $24-30$ \\
\hline I & 5.86 & 18.14 & 28.56 & 25.36 & 17.56 \\
II & 4.40 & 15.33 & 32.09 & 31.88 & 37.00 \\
III & 7.00 & 4.95 & 12.90 & 12.65 & 47.18 \\
IV & 8.56 & 13.40 & 12.20 & 9.76 & 25.15 \\
V & 12.40 & 12.44 & 19.05 & 15.44 & 6.93 \\
& & & & & \\
\hline
\end{tabular}

(Table 4). Oxygen-to-nitrogen ratios of approximately 7 indicate that protein is the sole substrate used for energy production, while increasing values are interpreted as an increasing reliance on carbohydrates and/ or lipids. For rock crab larvae cultured at $10{ }^{\circ} \mathrm{C} / 30 \% \mathrm{~S}$. the $\mathrm{O}: \mathrm{N}$ ratio was particularly low throughout development, suggesting that protein was the primary substrate used as an energy source. At the other culture conditions tested, the $\mathrm{O}: \mathrm{N}$ ratios remained above 7 during most of the developmental period, except in two instances (Stage III at $15^{\circ} \mathrm{C} / 25 \% \mathrm{~S}$ and Stage $\mathrm{V}$ at $24^{\circ} \mathrm{C} / 30 \% \mathrm{~S}$ ). 


\section{DISCUSSION}

The relationship of $\dot{V}_{0_{z}}$ to larval body size is one physiological parameter altered by culture conditions. Typically, this regression coefficient for most crustaceans falls between 0.67 and 1.00 (Wolvekamp and Waterman, 1960) and this has generally been the case for crustacean larvae (Mootz and Epifanio, 1974; Logan and Epifanio, 1978; Schatzlein and Costlow, 1978; Johns and Pechenik, 1980). The same has been seen here in larvae maintained in salinities of 25,30 and $35 \% \mathrm{~S}$ at $15^{\circ} \mathrm{C}$, and those maintained at $24{ }^{\circ} \mathrm{C} / 30 \% \mathrm{~S}$ exhibited regression coefficients of between 0.80 and 0.97 . However, larvae cultured at $10^{\circ} \mathrm{C} / 30 \% \mathrm{~S}$ had a regression coefficient of 1.34 . This is unusual and represents a significant deviation for this relationship. A high regression coefficient was also reported by Capuzzo and Lancaster (1979) for lobster (Homarus americanus) larvae. These authors did not advance an explanation for their high $b$ value (1.24), a value which is considerably higher than that $(0.66)$ found by Logan and Epifanio (1978) for lobster larvae cultured under similar conditions. One possible cause for the deviation in the basic relationship between body weight and oxygen consumption in any species may be that the organisms were under physiological stress; this can be induced by culture conditions. For rock crab larvae, $10^{\circ} \mathrm{C}$ represents a limiting temperature with only $20 \%$ of the larvae maintained at this temperature completing larval development to the megalopa stage (Johns, 1981). Since metabolic responses of marine organisms change at the thermal limits (Vernberg and Vernberg, 1970 ) it might be expected that the allometric relationship would also be affected

Weight-specific respiration rates $\left(\bar{Q}_{0}\right)$ of larvae cultured at $10{ }^{\circ} \mathrm{C} / 30 \%$ S and at 25,30 , and $35 \%$ S at $15^{\circ} \mathrm{C}$ tended to change little during development, indicating little stage-specific sensitivity to temperature and/or salinity. Larvae cultured in $24{ }^{\circ} \mathrm{C} / 30 \% \mathrm{~S}$ exhibited some slight temperature sensitivity during late zoeal development. Sensitivity of rock crab larvae to thermal conditions have also been reported by Sastry and McCarthy (1973) on studies detailing larval metabolictemperature responses. Larvae were found to be more stenothermal during late larval development than during the earlier stages of development.

At a particular set of environmental conditions, weight-specific respiration rates typically decrease as an organisms grows and develops due to a disproportionate increase in tissue of low metabolic rate (Prosser, 1973). However, comparable literature values for other crustacean larvae indicate that this pattern may not follow for all crustacean larvae. Larvae of the stone crab Menippe mercenaria (Mootz and Epifanio, 1974) follow the expected pattern, as do larvae of Emerita talpoida (Schatzlein and Costlow, 1978; their Fig. 3). On the other hand, Capuzzo and Lancaster (1979) reported that weight-specific respiration rates for lobster larvae increase rather than decrease during larval development. Both the data of Sastry (1979) and that in this study, however, indicate that the weight-specific respiratory rate of Cancer irroratus larvae does not change during larval development. The same was also seen in Libinia emarginata larvae (Schatzlein and Costlow; 1979, their Fig. 3).

The reason for the above contrasting observations are not known. In developing crustacean larvae, there may not necessarily be an increase in low metabolic tissue, if major morphological and physiological changes do not occur during zoeal development such as suggested by Costlow (1968). The general tissue types present in late stage larvae and their metabolic activity may be similar to those present in larvae at hatching. Hence, metabolic demands per unit weight would remain unchanged. In support of this argument, Sulkin et al. (1975) found that larval development of the brachyuran Rhithropanopeus harrisii was due primarily to an increase in cell size rather than due to an increase in cell number or cell types. Also, the sequence of changes in different organ systems in the naupliar stages of the barnacle Balanus balanoides has been reported as slight with no major changes occurring until metamorphosis to the cyprid stage (Walley, unpubl. in Costlow, 1968).

In contrast to the amount of data available on the effects of body size and environmental conditions on respiratory rates, little is known concerning body size excretory rate relationships. Bayne and Scullard (1977) working with the adult mussel Mytilus edulis and Capuzzo and Lancaster (1979) working with Homarus americanus larvae have reported regression coefficients in excess of 1.00 for the allometric relationship of excretion rates to body size. This is in agreement with those values reported here for rock crab larvae. In addition, Bayne and Scullard (1977) found that the allometric relationship between excretion rates and size in the mussel was temperature independent, a fact also seen in the present study. Rates of ammonia production for a given size class of crab larvae, however, was significantly greater in larvae maintained at $24{ }^{\circ} \mathrm{C} / 30 \% \mathrm{~S}$ and $10{ }^{\circ} \mathrm{C} / 30 \%$ S than for larvae cultured at $15^{\circ} \mathrm{C} / 30 \% \mathrm{~S}$. Salinity on the other hand affected both the excretion rate weight relationship as well as the amount of ammonia liberated per unit weight Excretion rates increased as salinity decreased, with rates at $25 \%$ S substantially greater than that in larvae maintained at 30 and $35 \%$ S. Similar results have been reported for a variety of species and appears to be associated with the osmoregulatory mechanism (Emerson, 1969; Pandian, 1975; Kinne, 1976). 
Although instances where physiological rates exceeded the normal range are indicative of physiological stress (Sastry and Miller, 1981), the measurement of individual physiological rate functions does not necessarily provide direct evidence that an organism's potential for survival will be reduced (Brett, 1958; Bayne, 1975). A better assessment of stress can be made by determining the atomic ratio of oxygen consumed to nitrogen excreted (Bayne, 1973; 1975; Widdows, 1978). An $O: N$ ratio not only provides a measure of the integration of physiological functions but also gives some indication of the catabolic balance between the energy substrates. Low $\mathrm{O}: \mathrm{N}$ ratios are indicative of protein being used as a source of energy; conversely, the higher the $\mathrm{O}: \mathrm{N}$ ratio, the more carbohydrates and/or lipids are being utilized (Corner and Cowey, 1968). Since the biochemical composition of crustacean larvae is mostly protein (Frank et al., 1975; Capuzzo and Logan, 1979), utilization of dietary and body protein as an energy source diverts this resource from growth to maintenance needs.

Mobilization of protein to meet metabolic demands presents several problems regarding completion of larval development. The ability of larvae to survive in a particular set of environmental conditions is dictated by its ability to compete with other organisms with similar tolerance limits (Newell and Branch, 1980), where rapid growth is typically the key to predator avoidance and food procurement. In the present study, rock crab larvae appeared to rely on more than one biochemical substrate for energy production, with the use of protein being dependent on the culture condition. Larvae maintained at $10{ }^{\circ} \mathrm{C} / 30 \% \mathrm{~S}$ were primarily using protein as an energy source while larvae in the other conditions appeared to be mobilizing carbohydrates and lipids to a greater extent in order to meet energy needs.

Larvae exhibit a capacity to compensate in most circumstances $\left(15^{\circ}\right.$ to $24^{\circ} \mathrm{C}$ in 30 to $35 \%$ S), with their physiological rate functions being well within the range expected for brachyuran larvae. Under some conditions $\left(10^{\circ} \mathrm{C} / 30 \% \mathrm{~S} ; 15^{\circ} \mathrm{C} / 25 \%\right.$ S) however, there was a deviation from the norm for the physiological rates and a shift to protein as a source of energy. The physiological stress imposed on Cancer irroratus larvae in these conditions has the effect of reducing growth rates and increasing pelagic development times (Johns, 1981). This may represent a large loss of larvae prior to recruitment to the adult population since stressed larvae may be unable to compete for available food resources and avoid planktonic predators (Thorson, 1950; Vance, 1973; Strathmann, 1977). Hence, the successful development and recruitment of rock crab larvae to the benthos appears to be not only restricted by their tolerance limits, but is also influ- enced by conditions within these limits where physiological performance is impaired to such an extent that they are less fit to effectively compete within the zooplankton community.

Acknowledgements. This study was part of the dissertation submitted to the University of South Carolina, USA, in partial fulfillment of the requirements of the degree of Doctor of Philosophy. I wish to acknowledge the helpful comments and criticisms of colleagues and thesis committee members: Drs W. B. Vernberg, D. C. Miller, S. Stancyk, P. DeCoursey, R. Gardner and J. Scott. Portions of this research were supported by a United States Environmental Protection Agency Fellowship.

\section{LITERATURE CITED}

Bayne, B. L. (1973). Physiological changes in Mytilus edulis L. induced by temperature and nutritive stress. J. mar. biol. Ass. U. K. 53: 39-58

Bayne, B. L. (1975). Aspects of physiological conditions in Mytilus edulis I., with special reference to the effects of oxygen tension and salinity. In: Barnes, H. (ed.) Proceedings 9 th European Marine Biology Symposium. University Press, Aberdeen, pp. 213-238

Bayne, B. L., Scullard, C. (1977). Rates of nitrogen excretion by species of Mytilus (Bivalvia: Mollusca). J. mar. biol. Ass. U. K. 57 : 355-369

Belman, B. W., Childress, J. J. (1973). Oxygen consumption of the larvae of the lobster Panulirus interruptus (Randall) and the crab Cancer productus Randall. Comp. Biochem. Physiol. 44A: 821-828

Brett, J. R. (1958). Implication and assessments of environmental stress. In: Larkin, P. A. (ed.) The Investigation of fish power problems. University of British Columbia Press, Vancouver, pp. 69-83

Capuzzo, J. M., Lancaster, B. A. (1979). Some physiological and biochemical considerations of larval development in the American lobster, Homarus americanus Milne Edwards. J. exp. mar Biol. Ecol. 40:53-62

Christiansen, M. E., Costlow, J. D., Jr. (1975). The effect of salinity and cyclic temperature on larval development of the mud crab, Rhithropanopeus harrisii (Brachyura: Xanthidae) reared in the laboratory. Mar Biol. 32: 215-221

Corner, E. D. S., Cowey, C. B. (1968). Biochemical studies on the production of marine zooplankton. Biol. Rev. 43: $393-426$

Costlow, J D., Jr. (1968). Metamorphosis in crustaceans. In Etkins, W., Gilbert, L. I. (eds.) Metamorphosis: a problem in developmental biology. Appleton-Century Crofts, New York, pp. 3-42

Costlow, J. D., Jr., Bookhout, C. G. (1962). The larval development of Hepatus epheliticus (C.) under laboratory conditions. J. Elisha Mitchell scient. Soc. 78: 113-125

Costlow, J. D., Jr., Bookhout, C. G. (1971). The effects of cyclic temperatures on larval development in the mud crab Rhithropanopeus harrisii (Gould). In: D. J. Crisp (ed.) Proceedings 4 th European Marine Biological Symposium Cambridge University Press, Cambridge, pp. 211-220

Costlow, J. D., Jr., Bookhout, C. G., Monroe, R. (1966). Studies on the larval development of the crab Rhithropanopeus harrisii Gould. I. The effect of salinity and temperature on larval development. Physiol. Zool. 39: 81-100 
Emerson, D. N. (1969). Influence of salinity on ammonia excretion rates and tissue constituents of euryhaline invertebrates. Comp. Biochem. Physiol. 29: 1115-1133

Foskett, J. K. (1977). Osmoregulation in the larvae and adults of the grapsid crab, Sesarma reticulatum Say. Biol. Bull. mar biol. Lab., Woods Hole 153: 505-526

Frank, J. R., Sulkin, S. D. Morgan, R. P., II. (1975). Biochemical changes during larval development of the xanthid crab Rhitropanopeus harrisii. I. Protein, total lipid, alkaline phosphatase, and glutanic oxaloacetic transaminase. Mar Biol. 32: 105-111

Grunbaum, B. W., Siegel, B. U., Schulz, A. R., Kirk, P. (1955) Determination of oxygen uptake by tissue grown in an all glass differential microrespirometer Mikrochim. Acta 6: 1069-1075

Johns, D. M. (1980). Larval development and bioenergetics of Cancer irroratus (Say) larvae under optimal and sub-optimal conditions of tempterature and salinity. $\mathrm{Ph}$. D. thesis, University of South Carolina, Columbia

Johns, D. M. (1981). Physiological studies on Cancer irroratus larvae. I. Effects of temperature and salinity on survival, development rate and size. Mar. Ecol. Prog. Ser. 5: 75-83

Johns, D. M., Pechenik, J. A. (1980). The influence of the water-accommodated fraction of No. 2 fuel oil on energetics of larval Cancer irroratus. Mar. Biol. 55: 247-254

Johns, D. M., Peters, M. E., Beck, A. D. (1980). International study on Artemia. Nutritional value of geographical and temporal strains of Artemia sp: Effects on survival and growth of two species of brachyuran larvae. In: G. Persoone, P. Sorgeloos, O. Roels, E. Jaspers (eds.) The brine shrimp. Universa Press, Wetteren, Belgium. pp. 291-304

Kalber, F. A., Costlow, J. D., Jr (1966). The ontogeny of osmoregulation and its neurosecretory control in the decapod crustacean Rhithropanopeus harrisii. Am. Zool. 6: 221-229

Kalber, F. A., Costlow, J. D., Jr (1968). Osmoregulation in larvae of the land crab, Cardisoma guanhumi Latreille. Am. Zool. 8: 411-416

Kinne, O. (1970). Temperature: animals: invertebrates. In: Kinne, O. (ed.) Marine ecology, Vol. I, Environmental factors, Part 1. Wiley, London, pp. 407-514

Kinne, O. (1971). Salinity: animals: invertebrates. In: Kinne, O. (ed.) Marine ecology, Vol. I, Environmental factors, Part 2. Wiley, London, pp. 821-995

Kinne, O. (1976). Cultivation of marine organims: Waterquality management and technology. In: Kinne, O. (ed.) Marine ecology, Vol. III, Cultivation, Part 1. Wiley, Chichester, pp. 19-300

Kinne O. (1977). Cultivation of animals - research cultivation. In: Kinne, O. (ed.) Marine ecology, Vol. III, Cultivation, Part 2. Wiley, Chichester, pp. 579-1293

Logan, D. T., Epifanio, C. E. (1978). A laboratory energy balance for the larvae and juveniles of the American lobster, Homarus americanus. Mar. Biol. 47: 381-389

Mootz, C. A., Epifanio, C. E. (1974). An energy budget for Menippe mercenaria larvae fed Artemia nauplii. Biol. Bull. mar. biol. Lab., Woods Hole 146: 249-254

Morgan, R. P. II, Kramarsky, E., Sulkin, S. D. (1978). Biochemical changes during larval development of the xanthid crab Rhithropanopeus harrisii. III. Isozyme changes during ontogeny. Mar. Biol. 48: 223-226
Newell, R. C., Branch, G. M. (1980). The influence of temperature on the maintenance of metabolic energy balance in marine invertebrates. Adv. mar. Biol. 17: 329-396

Pandian, T J. (1975) Mechanisms of heterotrophy. In: Kinne, O. (ed.) Marine ecology, Vol. Ir. Physiological mechanisms, Part 1 Wiley, Chichester, pp. 61-250

Prosser, C. L. (1973). Oxygen: Respiration and metabolism. In: Prosser, C. L. (ed.) Comparative animal physiology. W. B. Saunders, Co., Philadelphia, pp. 165-211

Sastry, A. N. (1979). Metabolic adaptation of Cancer irroratus developmental stages to cyclic temperatures. Mar Biol. 51. 243-250

Sastry, A. N., Ellington, W. R. (1978). Lactate dehydrogenase during larval development of Cancer irroratus: Effect of constant and cyclic thermal regimes. Experientia 34: 308-309

Sastry, A. N., McCarthy, J. F. (1973). Diversity in metabolic adaptation of pelagic larval stages of two sympatric species of brachyuran crabs. Neth. J. Sea Res. 7: 434-446

Sastry, A. N., Miller, D. C. (1981). Application of biochemical and physiological responses to water quality monitoring In: Vermberg, F. J., Calabrese, A., Thurberg, F. P., Vernberg, W. B. Biological monitoring of marine organisms. Academic Press, New York, pp. 265-294

Schatzlein, F. C., Costlow, J. D., Jr. (1978). Oxygen consumption of the larvae of the decaped crustaceans, Emerita talpoida (Say) and Libinia emarginata Leach. Comp. Biochem. Physiol. 61 A: 441-450

Snedecor, G. W., Cochran, W G. (1967). Statistical methods, Iowa State University Press, Ames, Iowa

Solorzano. L. (1969). Determination of ammonia in natural waters by the phenolhypochlorite method. Limnol. Oceanogr. 14: 799-801

Strathmann, R. R. (1977). Toward understanding complex life cycles of benthic invertebrates. In: Costlow, J. D., Jr (ed.) The ecology of fouling communities. U. S. Office of Naval Research, U. S. Government Printing Office, Washington, D. C., pp. $1-20$

Sulkin, S. D., Morgan, R. P. II, Minasian, L. L., Jr (1975). Biochemical changes during larval development of the xanthid crab Rhithropanopeus harrisii. II. Nucleic acids. Mar Biol. 33: 113-117

Thorson, G. (1950). Reproductive and larval ecology of marine bottom invertebrates. Biol. Rev. 25: 1-45

Tucker, R. K. (1978). Free amino acids in developing larvae of the stone crab, Menippe mercenaria. Comp. Biochem. Physiol. 60A: 169-172

Vance, R. R. (1973). On reproductive strategies in marine benthic invertebrates. Am. Nat. 107: 339-352

Vernberg, F. J., Costlow, J. D., Jr (1966). Studies on the physiological variation between tropical and temperatezone fiddler crabs of the genus Uca. IV. Oxygen consumption of larvae and young crabs reared in the laboratory. Physiol. Zool. 39: 36-52

Vernberg, F. J., Vernberg, W. B. (1970). The animal and the environment, Holt, Rinehart and Winston, Inc., New York

Widdows, J. (1978). Physiological indices of stress in Mytilus edulis. J. mar. biol. Ass. U. K. 58: 125-142

Wolvekamp, H. P., Waterman, T. H. (1960). Respiration. In: Waterman, T. H. (ed.) The physiology of crustacea. Academic Press, New York, pp. 35-100 